\title{
Oocytes in sheep homozygous for a mutation in bone morphogenetic protein receptor 1B express lower mRNA levels of bone morphogenetic protein 15 but not growth differentiation factor 9
}

\author{
Janet L Crawford, Derek A Heath, Karen L Reader ${ }^{1}$, Laurel D Quirke ${ }^{1}$, Norma L Hudson, \\ Jennifer $L$ Juengel ${ }^{1}$ and Kenneth P McNatty \\ School of Biological Sciences, Victoria University of Wellington, PO Box 600, Wellington 6140, New Zealand and \\ ${ }^{1}$ AgResearch, Invermay Agricultural Centre, Puddle Alley, Private Bag 50013, Mosgiel, New Zealand
}

Correspondence should be addressed to J L Crawford; Email: janet.crawford@vuw.ac.nz

\begin{abstract}
The aim of this study was to test the hypothesis that the high ovulation rate in ewes (BB) homozygous for a mutation in the bone morphogenetic protein receptor type 1B $(B M P R 1 B)$ gene is linked to lower BMP15 and/or GDF9 mRNA in oocytes compared with those in wild-type $(++)$ ewes. Cumulus cell-oocyte complexes (COC) and granulosa cells (GC) were recovered from $\geq 1 \mathrm{~mm}$ diameter follicles of BB and ++ ewes during a prostaglandin-induced follicular phase. Expression levels of GDF9 and BMP15 were measured by multiplex qPCR from individual COC. The gonadotropin-induced cAMP responses of the GC from each non-atretic follicle were measured following treatment with FSH or human chorionic gonadotropin. In a separate validation experiment, GDF9 and BMP15 expression was present only in oocytes and not in cumulus cells. There was no effect of follicular diameter on oocyte-derived GDF9 or BMP15 mRNA levels. The mean expression levels of BMP15, but not GDF9, were significantly lower in all non-atretic follicles, including the subsets containing either FSH- or LH-responsive GC in BB, compared with ++ , ewes. No genotype effects were noted for FSH-induced cAMP production by GC either with respect to dose of, or number of follicles responding to, FSH. However, ovaries from BB ewes contained significantly more follicles responsive to $\mathrm{LH}$, with respect to cAMP production in GC. We propose that these findings are consistent with the hypothesis that the higher ovulation rate in BB sheep is due, at least in part, to lower oocyte-derived BMP15 mRNA levels together with the earlier onset of LH-responsiveness in GC.

Reproduction (2011) 142 53-61
\end{abstract}

\section{Introduction}

Ewes that inherit a mutation in the bone morphogenetic protein receptor type $1 \mathrm{~B}(B M P R 1 B$; also known as activin-like kinase 6) gene have significantly higher ovulation rates compared with their wild-type contemporaries (see reviews by McNatty et al. (2005) and Fabre et al. (2006)). These BMPR1B-mutant ewes are commonly referred to as Booroola ewes. It has been proposed that the Booroola mutation influences the level of oocytederived signalling, possibly via altered protein expression of BMP15 (McNatty et al. 2005) or via altered BMP15 signalling (Mulsant et al. 2001, Campbell et al. 2006). However to our knowledge, this has not been proven. In ewes heterozygous for an inactivating mutation in BMP15, such as the Inverdale (Fec $\left.X^{\top}\right)$ or Hanna $\left(\mathrm{Fec}^{\mathrm{H}}\right)$ genotype, it would be reasonable to expect lower levels of oocyte-secreted protein for BMP15 (Galloway et al. 2000). A physiological relationship between lower biologically active concentrations of BMP15 and higher ovulation rates has been demonstrated by immunising wild-type ewes against the entire mature BMP15 protein or small peptide sequences of the mature BMP15 region (Juengel et al. 2002, McNatty et al. 2007). Collectively, the evidence from both the immunisation and mutation studies indicates that as the dose of biologically available BMP15 decreases, the ovulation rate increases until BMP15 concentrations are too low to support follicular growth (McNatty et al. 2004, 2007, Fabre et al. 2006). At this point, animals become infertile, as is the case in homozygous BMP15mutant animals (Galloway et al. 2000, Scaramuzzi et al. 2011). The notion that altered BMP15 synthesis is in some way linked to the BMPR1B mutation is consistent with the observation that ewes with both an inactivating BMP15 mutation and BMPR1B mutation have ovulation rates that are more than additive (Davis et al. 1999, McNatty et al. 2005). 
Recently, the higher ovulation rates in Inverdale ewes were found to be associated with an earlier acquisition of $\mathrm{LH}$ (but not FSH) responsiveness by granulosa cells (GC) in a greater proportion of developing antral follicles (McNatty et al. 2009). In homozygous mutant Booroola (BB) ewes, ovarian follicles ovulate at smaller diameters (i.e. $>2.5-4.5 \mathrm{~mm}$ ) compared with those in the wildtype ewes (i.e. $>4.5 \mathrm{~mm}$ ), with the ovulating follicles in BB ewes each containing fewer GC (McNatty et al. 1986, Henderson et al. 1987). Moreover, similar to that which occurs in Inverdale ewes, GC in BB ewes develop a responsiveness to $\mathrm{LH}$ earlier in follicular development, consistent with the reduced size of the ovulating follicles (Henderson et al. 1987). It should be noted that although the GC in small (i.e. 1-2.5 mm) antral follicles of BB ewes also showed an increased sensitivity to FSH with respect to CAMP production (Henderson et al. 1987), the $\mathrm{FSH}$ preparations used in this experiment contained $>1 \%$ contamination of LH (McNatty et al. 2009).

The aim of this study was to test the hypothesis that the increased ovulation rate in BB ewes, compared with those in wild-type $(++)$ ewes, is linked, at least in part, to lower the mRNA expression levels of BMP15 and/or GDF9 in oocytes of follicles, particularly in those containing GC that are responsive to $\mathrm{LH}$ with regard to cAMP production.

\section{Results \\ Effect of genotype on ovulation rate}

The mean (and range of) ovulation rates based on the number of corpora lutea $(\mathrm{CL})$ present in the wild-type $(++)$ and homozygous mutant (BB) ewes were $2.8(2-5)$ and 9.7 (8-11) respectively.

\section{Effect of genotype on number of GC with respect to follicular diameter}

With respect to the number of GC present within follicles, there were significant main effects of follicular diameter $(P<0.001)$ and genotype $(P<0.001)$, but had no interactions (Fig. 1).

\section{Effects of dose, follicular diameter and genotype on FSH- or $\mathrm{LH}$-induced cAMP responses in GC}

Follicles described as FSH- or LH-responsive contained GC that resulted in the production of CAMP of $>10 \mathrm{pmol} / 10^{6}$ cells after treatment with either $\mathrm{FSH}$ or $\mathrm{LH}$ respectively. Those follicles that were defined as $\mathrm{LH}$-responsive also responded to $\mathrm{FSH}$ in $11 / 11$ follicles from ++ ewes and 25/26 follicles from BB ewes. The GC from the one (1/26) follicle from a BB ewe that was defined as LH-responsive, but not $\mathrm{FSH}$-responsive, elicited a cAMP response of $7 \mathrm{pmol} / 10^{6}$ cells after treatment with $1000 \mathrm{ng} / \mathrm{ml}$ of $\mathrm{FSH}$.

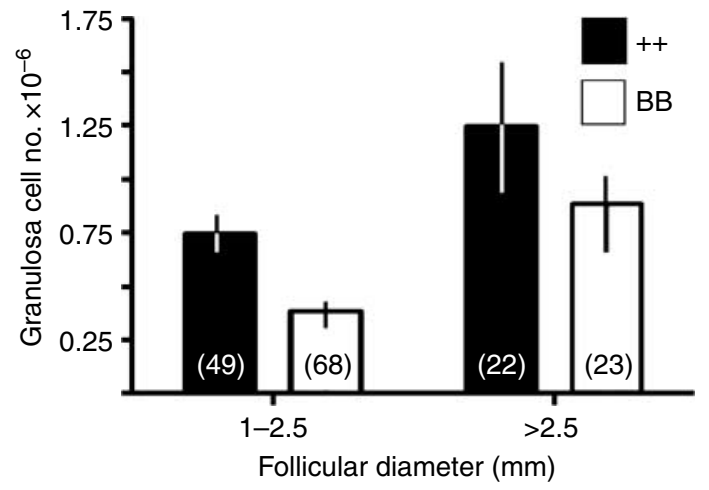

Figure 1 Effect of genotype and follicular diameter on number of granulosa cells (GC) present in non-atretic follicles. The numbers of GC are represented by black bars for wild-type $(++)$ ewes and white bars for homozygous Booroola mutant (BB) ewes. Values are expressed as geometric means and error bars denote $95 \%$ confidence limits. Numbers of follicles are shown in parentheses.

The effects of FSH dose, follicular diameter and genotype on FSH-induced cAMP response of GC are shown in Fig. 2. There were highly significant effects of dose $(10,100$ and $1000 \mathrm{ng} / \mathrm{ml} ; P<0.001)$ and follicular diameter $(1-2.5$ and $>2.5 \mathrm{~mm} ; P<0.001)$, but not genotype (Fig. 2), on $\mathrm{FSH}$-induced cAMP production in $\mathrm{GC}$ and no interactions were observed. The proportion of non-atretic follicles containing $\mathrm{FSH}$-responsive GC was similar $(P>0.05)$ between $++(36 / 48 ; 75 \%)$ and BB (34/50; 68\%) ewes.

There were significant effects of follicular diameter $(P<0.01)$ and genotype $(P<0.05)$ on $\mathrm{LH}$-induced cAMP production in GC, but no interactions were observed. The geometric mean (and 95\% confidence limits) levels for the LH-induced cAMP levels for 1-2.5 and $>2.5-4.5 \mathrm{~mm}$ diameter follicles in BB ewes were 4 $(2,10)$ and $16(6,46) \mathrm{pmol} / 10^{6} \mathrm{GC}$, respectively (no follicles $>4.5 \mathrm{~mm}$ diameter were present). For the ++ ewes, the cAMP values were $0.8(0.4,1.4), 3.2(0.6,17.0)$ and $29(6,132) \mathrm{pmol} / 10^{6} \mathrm{GC}$ for the $1-2.5,>2.5-4.5$ and $>4.5 \mathrm{~mm}$ diameter follicles respectively. The proportion of non-atretic follicles containing $\mathrm{LH}$-responsive GC was higher $(P<0.001)$ in BB $(26 / 50 ; 52 \%)$, compared with $++(11 / 48 ; 23 \%)$ ewes. This difference in the proportion of $\mathrm{LH}$-responsive follicles was due to responsiveness being attained in more smaller-sized follicles in BB ewes, compared with ++ ewes. Specifically, $41 \%$ of small $(1-2.5 \mathrm{~mm})$ and $54 \%$ of large $(>2.5 \mathrm{~mm})$ follicles were $\mathrm{LH}$-responsive in $\mathrm{BB}$ ewes compared with only 16 and $44 \%$, respectively, of those in ++ ewes.

\section{Specificity testing of GDF9 and BMP15 in dissociated cumulus cells and denuded oocytes}

The localisation of mRNA expression of GDF9 and $B M P 15$, together with gap junction protein alpha 4 (GJA4, also known as connexin $37(C X 37)$ a specific marker of oocytes), GJA1 (CX43) and FSHR (specific 


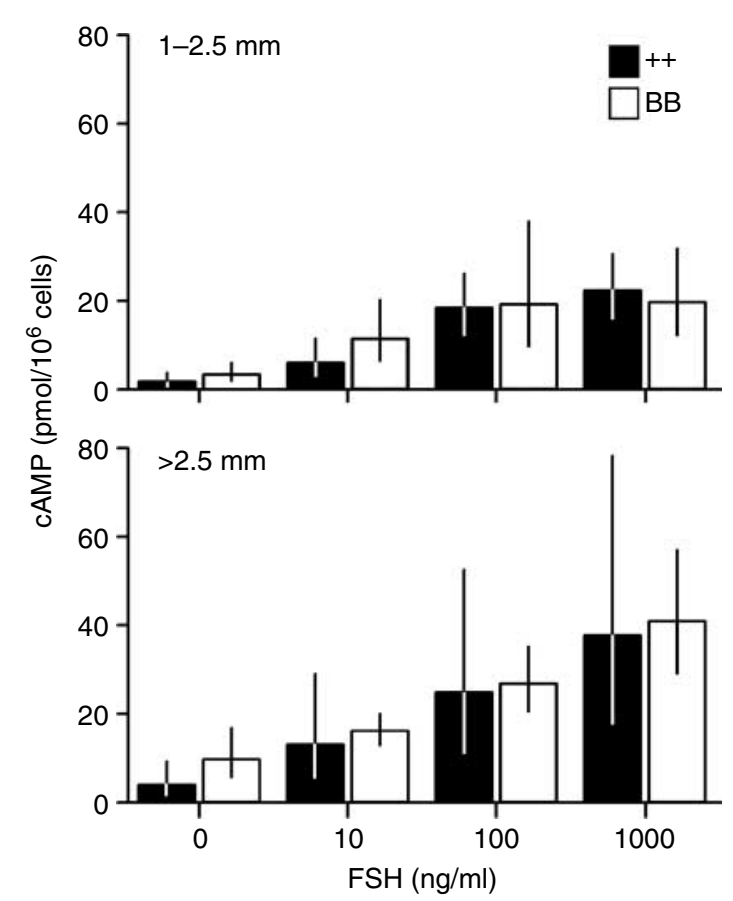

Figure 2 Effect of follicular diameter and dose of FSH on cAMP production by granulosa cells from follicles of wild-type $(++$; black bars) and homozygous Booroola mutant (BB; white bars) ewes combined. Follicles $1-2.5 \mathrm{~mm}$ in diameter are represented in the top graph and $>2.5 \mathrm{~mm}$ diameter are represented in the bottom graph. Values are expressed as geometric means and error bars denote $95 \%$ confidence limits. The number of observations across the doses for the $1-2.5 \mathrm{~mm}$ follicles is between 39 and 58 and for those $>2.5 \mathrm{~mm}$ is between 31 and 33 .

markers of granulosa and cumulus cells), within ovine cumulus cell-oocyte complexes (COC) is shown in Fig. 3. Expression of GDF9, BMP15 and GJA4 mRNA was present only in oocytes, whereas expression of GJA1 and FSHR mRNA was present only in the cumulus cells.

\section{Effect of follicular health, genotype and gonadotropin- responsiveness of $G C$ on relative expression levels of GDF9 and BMP15 mRNA in oocytes}

These data are summarised in Table 1. The mRNA values for GDF9 and BMP15 with respect to follicular health, genotype and gonadotropin-responsiveness of GC were corrected against a control (calibrator) sample containing differing amounts of GDF9 and BMP15 mRNA, and are referred to herein as relative mRNA levels. Hence, comparisons of the mRNA expression levels of GDF9 within and between genotypes and of BMP15 within and between genotypes were made with relative mRNA expression levels. Also given in Table 1 are the ratios for GDF9/BMP15 mRNA with respect to follicular health, genotype and gonadotropin-responsiveness of GC. These ratio values were obtained by comparing cycle threshold (Ct) values, and were not corrected against the calibrator sample.
There was no significant effect of follicular diameter on the mean relative expression levels of either GDF9 or BMP15 mRNA (data not shown). For both genes, relative expression levels were higher in non-atretic versus atretic follicles. The mean relative GDF9 mRNA expression levels were similar between genotypes. For the follicles containing GC that were responsive to $\mathrm{LH}$, the relative GDF9 mRNA levels in BB, compared with ++ , ewes tended to be lower $(P=0.062)$ but was not significantly different. Conversely, with respect to relative BMP15 expression levels, a significant effect of genotype was noted for oocytes from non-atretic follicles and from the subsets of $\mathrm{FSH}$ - and $\mathrm{LH}$-responsive follicles. In all instances, the relative $B M P 15$ mRNA levels were lower in oocytes from the BB ewes $(P<0.05)$. The mean ratios of GDF9:BMP15 irrespective of follicular health for the ++ and $B B$ genotypes were $1.19 \pm 0.04$ and $1.26 \pm 0.04$ respectively. These tended to be higher in the BB ewes $(P=0.05)$, with a greater number $(P<0.05)$ of COC with a GDF9:BMP15 ratio of $>1.1$ in BB compared with ++ ewes. However, no genotype differences were noted for GDF9:BMP15 ratios when follicles were further classified into healthy, atretic or with $\mathrm{FSH}$ - or LH-responsive GC (Table 1).

The cycle threshold $(\mathrm{Ct})$ values indicating the expression levels of GDF9 and BMP15 within individual oocytes of ++ and $\mathrm{BB}$ ewes were highly correlated (Fig. $4 ;++, R^{2}=0.9362, P<0.0001 ; \mathrm{BB}, R^{2}=0.9364$, $P<0.0001)$.

\section{Discussion}

The key findings from this study were that GDF9 and BMP15 mRNA are expressed exclusively by oocytes in the COC; GDF9 and BMP15 mRNA levels are strongly correlated in both genotypes; and BMP15, but
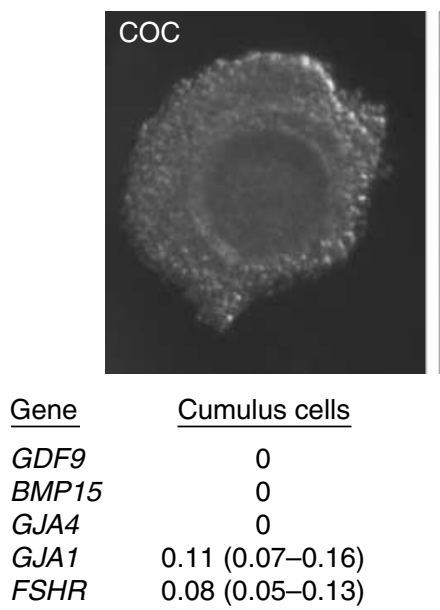

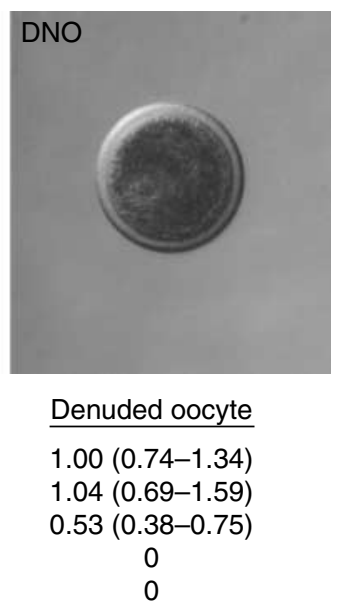

Figure 3 Relative gene expression levels of GDF9, BMP15, GJA4, GJA1 and FSHR in cumulus cells and denuded oocytes from individual cumulus cell-oocyte complexes $(n=6)$. Values are corrected for RPL 19 (housekeeping gene) and expressed as means (and errors) relative to the mean value of oocyte-derived GDF9 mRNA expression. 
Table 1 Relative expression levels of GDF9 and BMP15 mRNA, and GDF9/BMP15 ratios of cumulus cell-oocyte complexes, with respect to genotype, follicular health and cAMP responsiveness of granulosa cells (GC) to either FSH or LH, from homozygous Booroola mutant (BB) and wild-type $(++)$ ewes.

\begin{tabular}{|c|c|c|c|c|c|c|}
\hline \multirow[b]{2}{*}{ Follicular type } & \multicolumn{2}{|c|}{ GDF9 } & \multicolumn{2}{|c|}{ BMP15 } & \multicolumn{2}{|c|}{ GDF9/BMP15 ratios } \\
\hline & ++ & $\mathrm{BB}$ & ++ & BB & ++ & BB \\
\hline Non-atretic & $0.72 \pm 0.06^{\mathrm{a}}$ & $0.66 \pm 0.06^{\mathrm{a}}$ & $0.91 \pm 0.07^{\mathrm{a}}$ & $0.67 \pm 0.06^{b}$ & $\begin{array}{l}1.19 \pm 0.05^{a} \\
n=56\end{array}$ & $\begin{array}{l}1.22 \pm 0.05^{\mathrm{a}} \\
n=73\end{array}$ \\
\hline Atretic & $0.42 \pm 0.06^{\mathrm{a}, *}$ & $0.42 \pm 0.06^{\mathrm{a}, *}$ & $0.52 \pm 0.09^{\mathrm{a}, *}$ & $0.49 \pm 0.10^{\mathrm{a}, *}$ & $\begin{array}{l}1.14 \pm 0.06^{\mathrm{a}} \\
n=26\end{array}$ & $\begin{array}{l}1.23 \pm 0.04^{\mathrm{a}} \\
n=30\end{array}$ \\
\hline With FSH-responsive GC & $0.78 \pm 0.06^{\mathrm{a}}$ & $0.72 \pm 0.06^{\mathrm{a}}$ & $0.99 \pm 0.08^{\mathrm{a}}$ & $0.63 \pm 0.07^{b}$ & $\begin{array}{l}1.10 \pm 0.03^{\mathrm{a}} \\
n=36\end{array}$ & $\begin{array}{l}1.35 \pm 0.13^{\mathrm{a}} \\
n=30\end{array}$ \\
\hline With LH-responsive GC & $1.02 \pm 0.12^{\mathrm{a}}$ & $0.66 \pm 0.12^{\mathrm{a}}$ & $1.06 \pm 0.17^{\mathrm{a}}$ & $0.67 \pm 0.09^{b}$ & $\begin{array}{l}1.24 \pm 0.08^{\mathrm{a}} \\
n=7\end{array}$ & $\begin{array}{l}1.20 \pm 0.04^{\mathrm{a}} \\
n=23\end{array}$ \\
\hline
\end{tabular}

Values are expressed as means \pm s.E.M. The number of observations for each genotype is indicated in the ratio column. For each variable (GDF9, $B M P 15$ or GDF9/BMP15 ratio), values in each row with different alphabetical superscripts are significantly different $(P<0.05)$ from one another. Asterisks indicate that the values for atretic follicles are significantly $(P<0.05)$ lower than those for the non-atretic follicles for each genotype.

not GDF9, mRNA levels in oocytes of BB ewes were lower than that in oocytes of ++ ewes. The finding from our QPCR studies that GDF9 and BMP15 mRNA are expressed only in oocytes supports previously published in situ hybridisation (ISH) and immunohistochemistry data (Galloway et al. 2000, McNatty et al. 2005, 2006). Recent studies in mice, pigs and humans have suggested that BMP15 and GDF9 are present in granulosa and/or cumulus cells as well as in oocytes of large antral follicles (Margoulis et al. 2009, Sun et al. 2010). It could be argued that ISH is not sufficiently sensitive to detect the low expression levels of BMP15 or GDF9 mRNA in granulosa or cumulus cells. However, the evidence from this study shows clearly that GDF9 and BMP15 mRNA were expressed exclusively in oocytes, and not in surrounding somatic cells devoid of oocyte contamination, of antral follicles at various developmental stages in sheep. The highly correlative relationship between mRNA expression levels of GDF9 and BMP15, regardless of genotype, suggests that the regulation of these genes is very tightly regulated with expression levels higher in non-atretic than atretic follicles but with no effect of diameter of the antral follicles.

The evidence from this study that the BMP15 mRNA levels were lower in BB compared with ++ ewes supports the notion that the oocyte is implicated in influencing the ovulation rate in these animals. It is possible that the GDF9 mRNA levels in follicles with LH-responsive GC were also lower in BB than in wildtype ewes, but the sample size was not large enough for a statistical difference to be observed. It is known that ewes heterozygous for mutations in both BMP15 and GDF9 have ovulation rates that are greater than additive for each mutation alone (McNatty et al. 2005). Therefore, the possibility exists that both genes are expressed at lower levels and that both contribute to the high ovulation rates in these animals. However, until a significant effect for GDF9 is established in a larger study, only lower expression levels of BMP15 mRNA are able to be related to the higher ovulation rate in $\mathrm{BB}$ ewes.
Currently, seven different point mutations in the BMP15 gene and three in the GDF9 gene have been identified that influence ovulation rate in a number of different sheep breeds (see McNatty et al. (2005) and Paulini \& Melo (2011) for reviews). Moreover, in sheep carrying the Woodlands FecX2 ${ }^{\mathrm{W}}$ mutation that also affects ovulation rate, the expression levels of $B M P 15$, but not GDF9, mRNA are significantly lower than in the wild type. In FecX2 ${ }^{\mathrm{W}}$ animals, the mutation appears to be on the X-chromosome but has not been linked to any known mutation in the BMP15 gene (Feary et al. 2007). However, as is the case with the BB ewes, a downstream consequence is a reduced expression level of BMP15 mRNA (Feary et al. 2007). Moreover, the results raise the possibility that, at least in part, one common mechanism might exist between ewes with the BMP15, Woodlands and the BMPR1B (Booroola) mutations in that all may have lower BMP15 protein levels in the developing

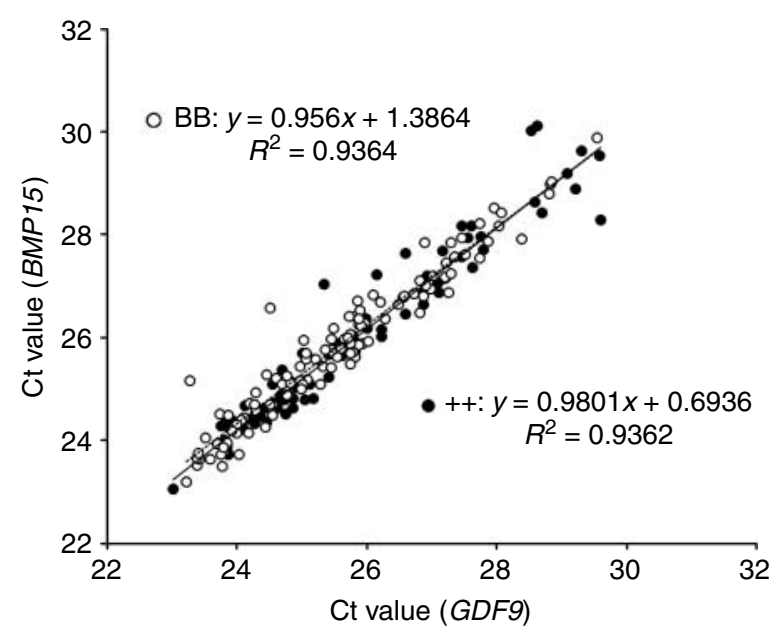

Figure 4 Regression plots of cycle threshold (Ct) values and lines of best fit for BMP15 and GDF9 genes from individual cumulus cell-oocyte complexes from wild-type ( ++ ; black circles; solid line) and homozygous Booroola mutant (BB; white circles; dashed line) ewes. Equations of lines of best fit and the coefficients of determination $\left(R^{2}\right)$ values are presented for both sheep genotypes. 
follicles. Of interest is that Inverdale and Booroola ewes have a greater proportion of follicles developing an earlier onset of LH-responsiveness and thereby ovulating at a smaller diameter (McNatty et al. 2009; this study). However, whether the earlier acquisition of LH-responsiveness is directly due to lower concentrations of oocyte-secreted BMP15 protein will require further studies including the measurement of this growth factor in follicular fluid. Currently, no assay for the accurate measurement of BMP15 in biological fluid is available. Owing to a lack of sensitivity, quantification of BMP15 by western blotting using specific BMP15 antibodies would require pooling of follicular fluid from many follicles. Our initial attempts to quantify BMP15 in ovine follicular fluid using a western blotting procedure have been unsuccessful despite the application of an affinityenrichment step and a highly specific monoclonal antibody. A preferred alternative approach might be the application of a more sensitive two-site sandwich-based ELISA assay and a purified biologically active reference standard; however, this methodology is not yet available.

Although this study shows a decreased level of BMP15 expression in oocytes of BB ewes, the link between this finding and the signalling pathway via the mutant BMPR1B remains obscure. Fabre et al. (2003) examined the effects of the Booroola genotype on BMPR1B signalling activity in HEK-293 cells transiently transfected with BMPR2 and the wild type or mutant forms of BMPR1B. Their results showed an enhanced level of basal signalling activity but an absence of BMP4stimulated signalling activity in the transfected mutant cells compared with wild-type cells. Campbell et al. (2006) reported that BMP2, 4 or 6 augmented the effects of FSH- and insulin-like growth factor 1 (IGF1)-induced oestradiol production by GC in BB compared with that in ++ ewes, indicating a direct link among BMPs, BMPR1B and follicular somatic cell maturation. However, at present, the specific ligand(s) that interacts with BMPR1B and the associated type II receptor are not known. Possible candidates include BMP15, BMP15GDF9 heterodimeric complexes and BMP6 (McNatty et al. 2005, Juengel et al. 2006). It is unlikely that other BMPs such as 2, 4 and 7 are candidates as their expression levels in ovine follicular cells were undetectable by ISH (Juengel et al. 2006). Therefore, it is possible that the downstream consequences of the mutated BMPR1B in BB ewes are mediated solely via lower levels of expression of BMP15 mRNA, leading to lower concentrations of BMP15 protein within follicular fluid although additional ligand-induced signalling effects via BMPs other than BMP15 cannot be ruled out.

This study showed that non-atretic, antral follicles, in comparison with atretic follicles, expressed higher levels of BMP15 and GDF9 mRNA. A reduction in mRNA levels of these growth factors in atretic follicles is likely to be due to the reduced support to the oocyte through the loss of cell-to-cell contacts between the GC, and between the GC and the oocyte (Wiesen \& Midgley 1994, Lenhart et al. 1998, Carabatsos et al. 2000). The cAMP responses induced by $\mathrm{FSH}$ were influenced by follicular diameter and dose of $\mathrm{FSH}$, which is consistent with our earlier observations (Henderson et al. 1987). Previously, we also reported a genotype difference in the sensitivity of GC to FSH as well as LH (Henderson et al. 1987). However, we now know that the FSH preparation was contaminated with $\sim 1-2 \%$ LH (McNatty et al. 2009). In this study, the highly purified FSH preparation contained no measurable $\mathrm{LH}$ (i.e. $<0.002 \%$ ) and there was no genotype effect of FSH on cAMP production. Thus, as with heterozygous BMP15-mutant Inverdale ewes (McNatty et al. 2009), the early maturation of antral follicles observed in BB ewes is unlikely to be due to a greater sensitivity to $\mathrm{FSH}$, as known previously (Henderson et al. 1987).

Despite the genotype difference in levels of $B M P 15$, but not GDF9, mRNA, the mean ratios of GDF9:BMP15 mRNA in individual oocytes were not different between the genotypes, although the frequency of higher ratios was significantly lower in BB ewes. This is supported by a less positive slope of regression when $\mathrm{Ct}$ values for BMP15 and GDF9 in individual oocytes were plotted on the $y$ and $x$ axes, respectively, compared with that of ++ ewes. The lack of significant difference in the ratio values due to genotype is probably due to a combination of only a small difference between genotypes and substantial variability within individual oocytes. Despite this variability, the expression levels of GDF9 compared with BMP15 were similar $(\sim 1.2)$ irrespective of follicular diameter, health or gonadotropin-responsiveness. Earlier studies on assessing the production of BMP15 and GDF9 proteins following co-transfection of $293 T$ cells indicate complex intracellular interactions between BMP15 and GDF9, indicating that the processing and secretion of these genes are not independent (see review by Moore \& Shimasaki (2005)). This study clearly demonstrates that their expression levels are also unlikely to be independent of one another. Thus, the expression ratios of GDF9:BMP15 are likely to have significant effects on downstream processing and in BMP15 and GDF9 protein levels. It is likely that the expression ratios of GDF9:BMP15 mRNA will vary between mono- and poly-ovulatory species. For example, the rodent is thought to have little or no BMP15 protein expressed throughout the majority of follicular development (Hashimoto et al. 2005). Our preliminary evidence suggests that, indeed, the expression ratios of GDF9 and BMP15 vary between multiple and low ovulation rate species (Crawford \& McNatty 2011).

Significant effects of genotype and follicular diameter were noted for human chorionic gonadotropin (hCG)/LH-responsive follicles, consistent with our earlier report (Henderson et al. 1987). That is, a much larger proportion of follicles $\geq 1 \mathrm{~mm}$ diameter responded to $\mathrm{LH}$ in BB, compared with ++ , ewes. This increase in the 
proportion of $\mathrm{LH}$-responsive follicles in $\mathrm{BB}$ ewes was due mainly to more follicles of a smaller $(1-2.5 \mathrm{~mm})$ size attaining LH-responsiveness. In this study, the number of LH-responsive follicles was $11(N=4)$ in ++ , and $26(N=3)$ in $B B$, ewes. If all these follicles went on to ovulate, this would correspond to ovulation rates of 2.75 and 8.7 in ++ and $\mathrm{BB}$ ewes respectively. The numbers of $\mathrm{CL}$ observed from the previous ovulatory cycle were 2.8 and 9.7 for ++ and $\mathrm{BB}$ ewes respectively. Interestingly, one of the ++ ewes contained five $\mathrm{CL}$, which is rare for wild-type Romney ewes. However, the ovaries from these ewes contained follicles that were typical of those in ++ ewes, i.e. characteristically larger follicles with more GC. Importantly, oocytes recovered from $\mathrm{LH}$-responsive follicles of $\mathrm{BB}$, compared with ++ , ewes had lower BMP15 but not GDF9, mRNA levels. This finding is consistent with the overall hypothesis that the higher ovulation rate in $\mathrm{BB}$ ewes is linked to the timing of onset of LH-responsiveness in developing follicles and this in turn might be regulated by oocytederived BMP15.

In conclusion, using a qPCR approach, these studies confirm for sheep that the expression of GDF9 and BMP15 mRNA in COC is specific to oocytes and is tightly regulated and influenced by follicular health. Additionally, we confirm that a greater proportion of ovarian follicles $\geq 1 \mathrm{~mm}$ diameter in $\mathrm{BB}$ ewes attain LH-responsiveness earlier in development compared with that in ++ ewes. This study has established that there are no genotype effects of $\mathrm{FSH}$-responsiveness in follicles. A major new finding is that oocytes from nonatretic follicles, FSH-responsive follicles and presumptive pre-ovulatory follicles (i.e. LH-responsive) in the $\mathrm{BB}$ ewes expressed less BMP15 mRNA compared with that in wild types. Therefore, we propose that the common pathway to higher ovulation rates in BB ewes is similar, at least in part, to that in heterozygous BMP15-mutant ewes and that the oocyte plays a role in this pathway.

\section{Materials and Methods}

All experiments were performed with the approval of the Invermay Animal Ethics Committee in accordance with the 1999 Animal Welfare Act (Part 6) of New Zealand. All animals had access to pasture and water ad libitum.

\footnotetext{
Animals

The animals in this study were 5-7-year-old Booroola Romney wild-type $(++; N=4)$ or Booroola Romney homozygous BMPR 1B-mutant ewes (BB; $N=3$ ). The ++ and BB ewes were derived from mating animals of known pedigrees. The ovaries of all animals were collected $24 \mathrm{~h}$ after the onset of a follicular phase, as induced by prostaglandin $\mathrm{F}_{2 \alpha}\left(\mathrm{PGF}_{2 \alpha}\right)$ treatment on days $10-11$ of the luteal phase of the oestrous cycle.
}

\section{Ovarian collection and recovery of $C O C$ and $G C$}

Ovaries were extracted, weighed and collected into saline $(0.9 \%)$ containing $20 \mathrm{mM}$ Hepes buffer ( $\mathrm{pH} 7.4)$. Thereafter, all follicles $\geq 1 \mathrm{~mm}$ diameter and $\mathrm{CL}$ were dissected at room temperature in DMEM supplemented with $20 \mathrm{mM}$ Hepes buffer, $0.2 \mathrm{mM}$ 3-isobutyl-methyl-xanthine (Sigma Chemical Co.) and $0.1 \%(\mathrm{w} / \mathrm{v})$ BSA (>97\% pure; ImmunoChemical Products Ltd, Auckland, New Zealand). The numbers and weights of $\mathrm{CL}$ were recorded. Each individual follicle was transferred into a dry petri dish, and the diameter was measured using a graticule in the eyepiece of the dissecting microscope before puncture for release of intra-follicular contents. The COC was then recovered in 2-4 $\mu$ l of follicular fluid, snap frozen and stored at $-80{ }^{\circ} \mathrm{C}$ until total RNA extraction. The remaining follicular fluid was carefully removed from the dish and stored at $-20{ }^{\circ} \mathrm{C}$ in $100 \mu \mathrm{l}$ PBS. Thereafter, $1 \mathrm{ml}$ of DMEM was added to the petri dish, and the GC were scraped from the inner wall of the follicle. The number of GC per follicle was determined by haemocytometer and the health status of each individual follicle was determined as described earlier (McNatty et al. 1986). In brief, non-atretic follicles were those defined as having a vascularised theca interna, the absence of debris in follicular fluid and a normal-looking COC and $\geq 25 \%$ of the maximum predetermined number of GC for a given diameter. Atretic follicles were considered to be those that fail one or more of the above criteria. In those atretic follicles, COC were collected for further analyses but GC were discarded.

For individual non-atretic follicles, the GC were centrifuged at $300 \mathrm{~g}$ at room temperature for $5 \mathrm{~min}$, and the resulting cell pellets were resuspended in the aforementioned DMEM medium to a final concentration of 60000 cells per incubation. Cells were incubated with or without FSH (0, 10, 100 and $1000 \mathrm{ng} / \mathrm{ml})$ or hCG $(100 \mathrm{ng} / \mathrm{ml})$ in triplicate in a final volume of $600 \mu \mathrm{l}$ in 48-well culture plates incubated in a water bath at $37^{\circ} \mathrm{C}$ for $45 \mathrm{~min}$. When insufficient numbers of cells were collected to undertake all treatments (e.g. in follicles 1-2.5 mm diameter), the minimum treatment regime was the inclusion of a control, a high dose of FSH $(1000 \mathrm{ng} / \mathrm{ml})$ and hCG $(100 \mathrm{ng} / \mathrm{ml})$ in duplicate. Under this regime, over $70 \%$ of all non-atretic follicles $1-2.5 \mathrm{~mm}$ diameter and $>95 \%$ of all nonatretic follicles $>2.5 \mathrm{~mm}$ were analysed for cAMP production in response to treatment. After the $45 \mathrm{~min}$ incubation period, samples were heated to $80{ }^{\circ} \mathrm{C}$ for $15 \mathrm{~min}$ and then stored at $-20{ }^{\circ} \mathrm{C}$ until assayed for cAMP.

\section{$F S H$ and $L H$ reagents}

The ovine FSH preparation was a highly purified in-house ovine reagent (oFSH Wal; McNatty et al. 2009). This reagent had a bioactivity of $1.4 \times$ USDA-oFSH-19-SIAFP or $33000 \mathrm{IU} /$ mg when the human FSH International Reference Preparation $78 / 549$ was used as a standard in a radio-receptor assay (Cheng 1975). The level of LH contamination was $<0.002 \%$ as determined by bioassay. The $\mathrm{LH}$ reagent was the hCG preparation CR121 (13 $450 \mathrm{IU} / \mathrm{mg}$ ) supplied by the National Institutes of Child Health and Development, Bethesda, MD, USA. The reason for using hCG is that it is devoid of FSH 
activity, whereas most $\mathrm{LH}$ preparations have residual $\mathrm{FSH}$ contamination.

\section{Cyclic AMP RIA}

The CAMP assay was performed as described previously (McNatty et al. 2009), and had a detection limit of $0.2 \mathrm{pm} /$ $10^{6}$ cells and the intra- and inter-assay coefficients of variation were $<9 \%$. The in-house primary antibody had a crossreactivity of $9 \%$ with dibutyryl-cAMP, $<0.001 \%$ with cGMP and $\leq 0.0001 \%$ with AMP, ADP or ATP.

\section{Analyses of GDF9 and BMP15 mRNA}

All reagents used and procedures performed were according to the manufacturers' instructions. The expression levels of GDF9, BMP15 and RPL19 (housekeeping gene) mRNAs and of GJA4, GJA1 and RPL19 were determined in triplex reactions using a Taqman qPCR method. The expression levels of FSHR and RPL19 were determined in singleplex reactions using a SYBR green qPCR method.

Total RNA was extracted from frozen individual COC using reagents from the ArrayPure Nano-Scale RNA Purification kit (Epicentre Biotechnologies, Madison, WI, USA). To remove any genomic DNA, the kit protocol included the incubation of each sample with DNase I for $30 \mathrm{~min}$. Following total RNA extraction, each sample was re-suspended in $10 \mu \mathrm{l}$ of UltraPure DNase/RNase-free distilled water (Invitrogen). Owing to limited template, the entire DNase-treated total RNA sample was reverse-transcribed using reagents including oligo(dT) ${ }_{20}$ from the SuperScript VILO cDNA Synthesis kit (Invitrogen).

Primers and Taqman probes for all genes were designed for multiplex (Taqman) and singleplex (SYBR green) qPCR using the computer package 'Beacon Designer' (Premier Biosoft International, Palo Alto, CA, USA) and are listed in Table 2. Taqman probes and primers were manufactured by SigmaProligo (supplied by Proligo-France SAS 1, Paris France and Proligo-Singapore Pte Ltd, Helios, Singapore) and Invitrogen respectively.
A control experiment was performed to determine the localisation of gene expression of GDF9 and BMP15 in different cell types of the COC (i.e. cumulus cells and denuded oocytes). Single COC were extracted from sheep ovaries obtained from a nearby abattoir. Cumulus cells were separated from oocytes by repeated pipetting. Single cumulus cell masses and denuded oocytes were separately washed three times in PBS, and total RNA was extracted and cDNA synthesised as described earlier. For quantification of the expression levels of GDF9 and BMP15 mRNA, or of GJA4 and GJA1 mRNA, triplex reaction mixes were prepared containing primers and Taqman probes for ovine GDF9, BMP15 and RPL19 genes or ovine GJA4, GJA1 and RPL19 genes, respectively, at optimised concentrations (Table 2) and reagents supplied in the Brilliant Multiplex QPCR Master Mix kit (Stratagene, La Jolla, CA, USA). For quantification of the expression levels of FSHR mRNA, singleplex reaction mixes were prepared containing primers for ovine FSHR or RPL19 genes at optimised concentrations (Table 2) and reagents supplied in the 'Brilliant SYBR Green QPCR Master Mix' kit (Stratagene). Samples were prepared in duplicate by adding an aliquot of neat cDNA (3.12 $\mu \mathrm{l})$ into the prepared reaction mix (total volume of $52 \mu \mathrm{l}$ ) and then transferring two $25 \mu \mathrm{l}$ aliquots to adjacent $0.1 \mathrm{ml}$ strip tubes (Corbett Research Ltd, Mortlake, NSW, Australia). The amplification reaction was run on a Rotor-Gene 6000 multiplexing system (Corbett Research Ltd) using the following conditions: 1 cycle of $95^{\circ} \mathrm{C}$ for $10 \mathrm{~min}$; 40 cycles of $95{ }^{\circ} \mathrm{C}$ for $15 \mathrm{~s}$ and $60^{\circ} \mathrm{C}$ for $60 \mathrm{~s}$. Before analysis, serial dilutions ( $1: 1$ to $1: 64)$ of two samples were made in appropriate singleplex or triplex reactions to validate PCR reaction efficiency for each gene. This included the calculation of the line of best fit (slope \pm 0.1 ) for all genes tested when $\Delta \Delta C T$ was plotted against log (input total RNA), as well as comparing CT values $(<0.5$ cycles different) for identical samples for all mRNA transcripts in singleplex and multiplex reactions.

For quantification of the expression levels of GDF9 and BMP15 mRNA in experimental samples, a triplex reaction mix was prepared using $1.04 \mu \mathrm{l}$ of neat COC-derived cDNA and amplified under the same conditions as described earlier. Controls were incorporated in every run and included

Table 2 Sequence information and final concentrations (nM) of primers and Taqman probes for sheep GDF9, BMP15, GJA4, GJA1, FSHR and RPL19 genes for use in either triplex Taqman $\left({ }^{\lambda} G D F 9, B M P 15\right.$ and $R P L 19 ;{ }^{\psi} G J A 4, G J A 1$ and $\left.R P L 19\right)$ or singleplex SYBR green $\left({ }^{\delta} F S H R\right.$ and $\left.R P L 19\right)$ quantitative PCR reactions.

\begin{tabular}{|c|c|c|c|c|}
\hline Gene & Taqman probe $\left(5^{\prime}-3^{\prime}\right)$ & $\mathrm{nM}$ & Primers $\left(5^{\prime}-3^{\prime}\right)$ & $\mathrm{nM}$ \\
\hline \multirow[t]{2}{*}{ GDF9 } & \multirow[t]{2}{*}{ (6FAM)AGTCTCAGCCTCAGATTCCAACGCAGTCCTA(BHQ1) } & \multirow[t]{2}{*}{$50^{\lambda \psi}$} & F-ATTAGCCTTGATTCTCTGCCTTCTAG & $200^{\lambda}$ \\
\hline & & & R-GTGTCTCCСАССТAAATGGTTCAG & $200^{\lambda}$ \\
\hline \multirow{2}{*}{ BMP15 } & \multirow{2}{*}{ (HEX)AGAATGTCCCTCAGCCTTCCTGTGTCCCT(BHQ1) } & \multirow[t]{2}{*}{$50^{\lambda \psi}$} & F-AACCTTGTCAGTGAGCTGGTG & $200^{\lambda}$ \\
\hline & & & R-AGATACTCССАТTTGССТСААТСАG & $200^{\lambda}$ \\
\hline \multirow{2}{*}{ GJA4 } & \multirow{2}{*}{ (6FAM)TCCTCTTCGTCAGCACGCCCACCC(BHQ1) } & \multirow{2}{*}{$100^{\psi}$} & F-TTCСССАТСТСССАСАТССG & $200^{4}$ \\
\hline & & & R-TCGCGCCGAGACAGGTAG & $200^{\psi}$ \\
\hline \multirow[t]{2}{*}{ GJA1 } & \multirow[t]{2}{*}{ (HEX)CGGCACTCAAGCTGAATCCATAGATGTACCACT(BHQ1) } & \multirow[t]{2}{*}{$50^{\psi}$} & F-TCTTCAAGTCTGTCTTCGAGGTG & $200^{\psi}$ \\
\hline & & & R-CTGATGCGGGCAGGGATC & $50^{\psi}$ \\
\hline \multirow[t]{2}{*}{ FSHR } & \multirow{4}{*}{ (CY5) TTCTCATCCTCCTCATCCACGTTACCTTCTCGG(BHQ3) } & \multirow{4}{*}{$50^{\lambda \psi \delta}$} & F-AGGACAGCAAGGTGACAGAGATG & $100^{\delta}$ \\
\hline & & & R-GTAGTTTGGGCAGGTTGGAGAAC & $100^{\delta}$ \\
\hline \multirow[t]{2}{*}{ RPL19 } & & & F-TAAGCGAAAGGGTACTGCCAATG & $200^{\lambda \psi \delta}$ \\
\hline & & & R-TTCTTAGATTCACGGTATCGTCTGAG & $200^{\lambda \psi \delta}$ \\
\hline
\end{tabular}

HEX, 6FAM, CY5 are fluorophores, and BHQ1 and 3 are quenchers from Sigma-Proligo. 
randomly picked samples that underwent reverse transcriptionPCR with the exclusion of Superscript III/RNaseout enzyme mix to examine the effectiveness of DNase treatment, and reactions that omitted addition of template.

Quantification of samples was calculated using the $\Delta \Delta C T$ method (Livak \& Schmittgen 2001). The expression levels of GDF9, BMP15, GJA4, GJA1 and FSHR from samples from the control experiment (i.e. cumulus cells and denuded oocytes) were corrected for RPL19 mRNA levels. The expression levels of GDF9 and BMP15 in the experimental samples (i.e. COC) were relative to a calibrator sample (cDNA from ovine ovary) and not corrected for RPL19 mRNA levels as expression of this gene was not specific to oocytes. Therefore, GDF9 and BMP15 mRNA levels are per oocyte and not relative to total RNA input. The ratios of GDF9:BMP15 mRNA in individual COC was calculated by $1: 2^{-\left(\mathrm{C}_{\mathrm{T}} \mathrm{MPF} 9\right.}-\mathrm{C}_{\left.\mathrm{T}_{\mathrm{BMP} 15}\right)}$.

\section{Statistical procedures}

Levels of mRNA are expressed as means, and the variance range is estimated by evaluating the $2^{-\Delta \Delta C_{T}}$ value plus and minus the S.D. leading to asymmetric error distribution (Livak \& Schmittgen 2001). The effects of follicular diameter and genotype on GC number or expression levels of GDF9 and BMP15 mRNA were assessed by ANOVA. As there were no effects of follicular diameter or interactions with respect to GDF9 and BMP15 mRNA, the comparisons of genotype levels between non-atretic follicles, atretic follicles and FSH- or LH-responsive follicles were by done by Student's $t$-test or Mann-Whitney $U$ test if the variances were not equal. The comparisons between genotypes of the GDF9/BMP15 mRNA ratios were also assessed by Mann-Whitney $U$ test and the counts of ratios $>1.1$ were analysed by $\chi^{2}$ test. The adequacy of a linear fit to the regression of GDF9 and BMP15 mRNA levels in individual COC from both genotypes was confirmed by a residual plot. GC producing $>10 \mathrm{pmol} / 10^{6}$ cells $/ 45 \mathrm{~min}$ when incubated with either FSH or hCG were considered to be gonadotropin-responsive; this value was $>2 \times$ the overall SD response above that produced by cells without gonadotropin treatment. For analyses of cAMP data, the main effects of follicular diameter, FSH dose and genotype were assessed by ANOVA. The proportions of FSH- and LH-responsive GC with respect to genotype were assessed by $\chi^{2}$ analyses.

\section{Declaration of interest}

The authors declare that there is no conflict of interest that could be perceived as prejudicing the impartiality of the research reported.

\section{Funding}

The work was supported by funding from the New Zealand Foundation for Research Science and Technology (C10X0308 and UOAX0814) and in part by a Marsden Grant (08VUW-010).

\section{Acknowledgements}

We acknowledge Dr Lloyd Moore, AgResearch Invermay for the supply of the ovine FSH preparation, the National Institute of Child Health and Development, Bethesda, USA for the supply of hCG, and the Invermay farm staff for animal management.

\section{References}

Campbell BK, Souza CJH, Skinner AJ, Webb R \& Baird DT 2006 Enhanced response of granulosa and theca cells from sheep carriers of the FecB mutation in vitro to gonadotrophins and bone morphogenic protein-2, 4, and -6. Endocrinology 147 1608-1620. (doi:10.1210/en.2005-0604)

Carabatsos MJ, Sellitto C, Goodenough DA \& Albertini DF 2000 Oocyte-granulosa cell heterologous gap junctions are required for the coordination of nuclear and cytoplasmic meiotic competence. Developmental Biology 226 167-179. (doi:10.1006/dbio.2000.9863)

Cheng K-W 1975 A radioreceptor assay for follicle-stimulating hormone. Journal of Clinical Endocrinology and metabolism 41 581-589. (doi:10. 1210/jcem-41-3-581)

Crawford JL \& McNatty KP 2011 The expression level of oocyte-derived BMP15 relative to GDF9 may be a key determinant in regulating species differences in ovulation-rate. Proceedings of the 44th Annual Meeting for the Society for the Study of Reproduction, Portland, OR, USA. Abstract 636.

Davis GH, Dodds KG \& Bruce GD 1999 Combined effect of the Inverdale and Booroola prolificacy genes on ovulation rate in sheep. Proceedings of the Association for the Advancement of Animal Breeding and Genetics 13 74-77.

Fabre S, Pierre A, Pisselet C, Mulsant P, Lecerf F, Pohl J, Monget P \& Monniaux D 2003 The Booroola mutation in sheep is associated with an alteration of the bone morphogenetic protein receptor-IB functionality. Journal of Endocrinology 177 435-444. (doi:10.1677/joe.0.1770435)

Fabre S, Pierre A, Mulsant P, Bodin L, Di Pasquale E, Persani L, Monget P \& Monniaux D 2006 Regulation of ovulation rate in mammals: contribution of sheep genetic models. Reproductive Biology and Endocrinology 4 20. (doi:10.1186/1477-7827-4-20)

Feary ES, Juengel JL, Smith P, French MC, $\mathrm{O}^{\prime}$ Connell AR, Lawrence SB, Galloway SM, Davis GH \& McNatty KP 2007 Patterns of expression of messenger RNAs encoding GDF9, BMP15, TGFBR1, BMPR1B and BMPR2 during follicular development and characterization of ovarian follicular populations in ewes carrying the Woodlands FecX2W mutation. Biology of Reproduction 77 990-998. (doi:10.1095/biolreprod.107.062752)

Galloway SM, McNatty KP, Cambridge LM, Laitinen MP, Juengel JL, Jokiranta TS, McLaren RJ, Luiro K, Dodds KG, Montgomery GW et al. 2000 Mutations in an oocyte-derived growth factor gene (BMP15) cause increased ovulation rate and infertility in a dosage-sensitive manner. Nature Genetics 25 279-283. (doi:10.1038/77033)

Hashimoto O, Moore RK \& Shimasaki S 2005 Posttranslational processing of mouse and human BMP-15: potential implication in the determination of ovulation quota. PNAS 102 5426-5431. (doi:10.1073/pnas.0409533102)

Henderson KM, McNatty KP, O'Keeffe LE, Lun S, Heath DA \& Prisk MD 1987 Differences in gonadotrophin-stimulated cyclic AMP production by granulosa cells from booroola $x$ merino ewes which were homozygous, heterozygous or non-carriers of a fecundity gene influencing their ovulation rate. Journal of Reproduction and Fertility 81 395-402. (doi:10.1530/jrf.0.0810395)

Livak KJ \& Schmittgen TD 2001 Analysis of relative gene expression data using real-time quantitative PCR and the $2^{-\Delta \Delta C_{\mathrm{T}}}$ method. Methods 25 402-408. (doi:10.1006/meth.2001.1262)

Juengel JL, Hudson NL, Heath DA, Smith P, Reader KL, Lawrence SB, O'Connell AR, Laitinen MP, Cranfield M, Groome NP et al. 2002 Growth differentiation factor 9 and bone morphogenetic protein 15 are essential for ovarian follicular development in sheep. Biology of Reproduction 67 1777-1789. (doi:10.1095/biolreprod.102.007146)

Juengel JL, Reader KL, Bibby AH, Lun S, Ross I, Haydon LJ \& McNatty KP 2006 The role of bone morphogenetic proteins 2, 4, 6 and 7 during ovarian follicular development in sheep: contrast to rat. Reproduction 131 501-513. (doi:10.1530/rep.1.00958) 
Lenhart JA, Downey BR \& Bagnell CA 1998 Connexin 43 gap junction protein expression during follicular development in the porcine ovary. Biology of Reproduction 58 583-590. (doi:10.1095/biolreprod58.2.583)

Margoulis S, Abir R, Felz C, Nitke S, Krissi H \& Frisch B 2009 Bone morphogenetic protein 15 expression in human ovaries from fetuses, girls and women. Fertility and Sterility 92 1666-1673. (doi:10.1016/j. fertnstert.2008.08.119)

McNatty KP, Lun S, Heath DA, Ball K, Smith P, Hudson NL, McDiarmid J, Gibb M \& Henderson KM 1986 Differences in ovarian activity between booroola $X$ merino ewes which were homozygous, heterozygous and non-carriers of a major gene influencing their ovulation rate. Journal of Reproduction and Fertility 77 193-205. (doi:10.1530/jrf.0.0770193)

McNatty KP, Moore LG, Hudson NL, Quirke LD, Lawrence SB, Reader K, Hanrahan JP, Smith P, Groome NP, Laitinen M et al. 2004 The oocyte and its role in regulating ovulation rate: a new paradigm in reproductive biology. Reproduction 128 379-386. (doi:10.1530/rep.1.00280)

McNatty KP, Smith P, Moore LG, Reader K, Lun S, Hanrahan JP, Groome NP, Laitinen M, Ritvos O \& Juengel JL 2005 Oocyte-expressed genes affecting ovulation rate. Molecular and Cellular Endocrinology 234 57-66. (doi:10.1016/j.mce.2004.08.013)

McNatty KP, Lawrence S, Groome NP, Meerasahib MF, Hudson NL, Whiting L, Heath DA \& Juengel JL 2006 Meat and Livestock Association Plenary Lecture 2005. Oocyte signalling molecules and their effects on reproduction in ruminants. Reproduction, Fertility and Development 18 403-412. (doi:10.1071/RD05104)

McNatty KP, Hudson NL, Whiting L, Reader KL, Lun S, Western A, Heath DA, Smith P, Moore LG \& Juengel JL 2007 The effects of immunizing sheep with different BMP15 or GDF9 peptide sequences on ovarian follicular activity and ovulation rate. Biology of Reproduction 76 552-560. (doi:10.1095/biolreprod.106.054361)

McNatty KP, Heath DA, Hudson NL, Lun S, Juengel JL \& Moore LG 2009 Gonadotrophin-responsiveness of granulosa cells from bone morphogenetic protein 15 heterozygous mutant sheep. Reproduction 138 545-551. (doi:10.1530/REP-09-0154)

Moore RK \& Shimasaki S 2005 Molecular biology and physiological role of the oocyte factor, BMP15. Molecular and Cellular Endocrinology 234 67-73. (doi:10.1016/j.mce.2004.10.012)

Mulsant P, Lecerf F, Fabre S, Schibler L, Monget P, Lanneluc I, Pisselet C, Riquet J, Monniaux D, Callebaut I et al. 2001 Mutation in bone morphogenetic protein receptor-IB is associated with increased ovulation rate in Booroola Mérino ewes. PNAS 98 5104-5109. (doi:10.1073/pnas.091577598)

Paulini F \& Melo EO 2011 The role of oocyte-secreted factors GDF9 and BMP15 in follicular development and oogenesis. Reproduction in Domestic Animals 46 354-361. (doi:10.1111/j.1439-0531.2010.01739.x)

Scaramuzzi RJ, Baird D, Campbell B, Driancourt MA, Dupont J, Fortune J, Gilchrist R, Martin G, McNatty K, McNeilly A et al. 2011 Regulation of folliculogenesis and the determination of ovulation rate in ruminants: a review. Reproduction, Fertility, and Development 23 444-467. (doi:10. 1071/RD09161)

Sun RZ, Lei L, Cheng L, Jin ZF, Zu SJ, Shan ZY, Wang ZD, Zhang JX \& Liu ZH 2010 Expression of GDF-9, BMP-15 and their receptors in mammalian ovary follicles. Journal of Molecular Histology 41 325-332. (doi:10. 1007/s10735-010-9294-2)

Wiesen JF \& Midgley AR Jr 1994 Expression of connexin 43 gap junction messenger ribonucleic acid and protein during follicular atresia. Biology of Reproduction 50 336-348. (doi:10.1095/biolreprod50.2.336)

Received 25 November 2010

First decision 14 January 2011

Revised manuscript received 29 March 2011

Accepted 7 April 2011 